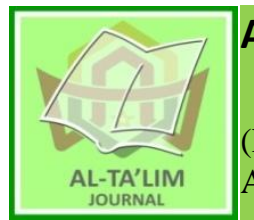

AL-TA'LIM JOURNAL, 25 (1), 2018, (13-21)

(Print ISSN 1410-7546 Online ISSN 2355-7893)

Available online at http://journal.tarbiyahiainib.ac.id/index.php/attalim

\title{
The Implementation of Augmented Reality Technology in Teaching Natural Sciences to Improve Elementary Students' Learning Achievement
}

Received: $18^{\text {th }}$ January 2018; Revised:13 ${ }^{\text {th }}$ February 2018; Accepted: $28^{\text {th }}$ February 2018

Permalink/DOI: http://dx.doi.org/10.15548/jt.v25i1.374

\section{Ali Fakhrudin}

Universitas Sebelas Maret, Surakarta, Indonesia.

E-mail: alifakhrudin12@gmail.com

\begin{abstract}
In this research, the researcher developed new innovation in natural sciences learning of elementary school by implementing augmented reality technology. The method that used in this research was research and development method based on Borg and Gall theory which consists often stages: 1) research and information collecting, 2) planning, 3) develop preliminary for more product, 4) preliminary field testing, 5) main product revision, 6) main field testing, 7) operational product revision, 8) operational field testing, 9) final product revision, 10) dissemination and implementation. The result of this research is learning media of natural sciences learning in elementary school by utilizing augmented reality technology. Based on the implementation of experiment, it is obtained the data that learning process using augmented reality which is developed can improve the students' learning achievement.
\end{abstract}

Keywords: Augmented reality; natural sciences; media; achievement.

How to cite: Fakhrudin, A. (2018). Implementation of augmented reality technology in teaching natural sciences to improve elementary students' learning achievement. Al-Ta Lim Journal, 25(1). doi:http://dx.doi.org/10.15548/jt.v25i1.374

\section{INTRODUCTION}

Based on the result of PISA (2009), Indonesia is on the second lowest rank from the 65 countries. There are three aspects that were researched by PISA, they are: the ability of reading, mathematics, and science (Baumert et al., 2001; Bybee, 2009). The result showed that science is on the lowest rank. This is apprehensive aspect which is measured by PISA is including the special skill in science field that is much needed in facing the global era challenge. Thus, science learning should be revised to be better. From those reasons, it becomes challenge for sciences teachers to teach science to the students maximally. One of the efforts is revising the learning system. In education field, science learning is called as natural sciences learning (Council, 2000; Duschl, 2008; Hurd, 1998). Natural science is collection of knowledge that is arranged systematically about natural indication. Natural science development is not only about fact, but also scientific method and scientific attitude. It is hoped that natural science education can be tool for students to learn surrounding nature. The continually prospect development can also be implemented in daily life (Depdiknas, 2008).

Based on the result of survey in Surakarta, it is showed that the score of natural science is lower than the others 
subjects. In conducting examination, the score of natural science is in the lowest rank compared with other subjects. On the national examination in academic year of 2013/104, the average of Indonesian language is 8, 26, mathematics 7. 38, while natural science is 7.29. Then, on the national examination in academic year of 2014/2015, the score of natural science has decreased significantly with average 62.43. Starting from that, it is a challenge for teachers to be able to convey the science lessons as much as possible to the students. One effort that can be done to maximize learning outcomes is by improvements in the learning system. Learning outcomes of students are influenced by internal factors and external factors. Internal factors including the students' interest and willingness in managing the material received.

External factors include the availability of media and the presence of a teacher in the learning process. Learning is a process of interaction between students and teachers, both in the classroom and outside of classroom by using learning source and learning media (Sanjaya, 2008; Trinova, 2012). Learning resources can be obtained from teachers, books, or printed media and other audio media that are expected to gain a wider knowledge (Karampiperis \& Sampson, 2005; Koper, 2003). Progress in education will not happen without improving the learning processed. In other words, the quality of education is strongly influenced by the quality of learning. Therefore, the lessons to be implemented should be adjusted to the mandate of Government Regulation No. 19of 2005 on National Education Standards, one of the standards to be developed is the process standard.

Then, to obtain good results in the learning process, it should be supported by the appropriate media that, because the learning media is an intermediary or the introduction of good communication and fun between teachers with students. The students' spirit will arise when the atmosphere is so fun and learning will be effective when they are happy in learning. Teachers' ability in designing and implementing learning media is the key to the success of fun learning process (Biggs, 2011; Dick, Carey, Carey, \& others, 2001; Hill \& Hannafin, 2001; Jimoyiannis, 2010; So \& Kim, 2009).

Grouping learning media are very diverse. Banks et al., (2005); Liu, (2010) classify the media in to two broad categories: traditional media and latest technology media. Learning media with modern technology usually involves emerging technologies such as cassette playback, video, recordings. While traditional media can be created manually by the teacher or containing classic elements by using materials and tools that are easily found in the environment. Teachers must be creative to create learning media in order to make learning condition more educative, effective, and efficient.

In this global era, the main multimedia is in form of ICT (Information technology and communication) becomes a fundamental requirement in determining the quality and effectiveness of the learning process. According to Neo \& Neo (2001) the process of learning using multimedia makes the learning is more deeply and fun, while for teachers the utilization of media is easier and very helpful in the process of effective learning. From Dryden and Vios (2003) study, it can be concluded from the results of their research that in successful education, self-image was more important than the learning materials. Thus, the concept of future education is directed to how to excite learners to learn in a fun way.

Nowadays, one of the trending technologies is Augmented Reality. Augmented Reality is combination between virtual and reality world made by computer (Feiner, Macintyre, \& Seligmann, 1993; Höllerer \& Feiner, 2004; Zhou, Duh, \& Billinghurst, 2008). The virtual object can be text, animation, 3D model or video that gathered with the real environment, so that 
the users can feel the virtual object is in their environment. Augmented Reality belongs to new technology branch. However, the development is fast. So far, this technology is used in various fields, especially in military and advertisement. And now, it started applying in education field. Elango (2013) in his research showed positive result in implementing Augmented Reality on mathematics learning. Then, (Chiang, Yang, \& Hwang, 2014) stated that there is increasing of students' understanding in learning science through media based Augmented Reality. Also, research by (Küçük, Yilmaz, \& Göktas, 2014; Van Krevelen \& Poelman, 2010) showed positive result in utilization of Augmented Reality in learning language.

In short, object can be seen more real through Augmented Reality. Therefore, it is very interesting if it is applied in learning process, especially in natural science, for it has man topics that can be learned through picture or visual (Bujak et al., 2013; Chittaro \& Ranon, 2007; Dunleavy, Dede, \& Mitchell, 2009; Kaufmann, 2003; Kaufmann \& Schmalstieg, 2003; Kaufmann, Schmalstieg, \& Wagner, 2000; Kirner, Reis, \& Kirner, 2012; Lee, 2012; Sommerauer \& Müller, 2014; Wojciechowski \& Cellary, 2013). Besides, Augmented Reality can be accessed via OS Android in phone facility.

Therefore, in this research, the researcher developed new innovation in natural science learning in elementary school. It is hoped that the problems above can be solved. The researcher developed assignment work sheet that utilize technology by using Augmented Reality system and can be accessed via android.

\section{METHOD}

Research design that was conducted is Research and Development (RD) that developing assignment work sheet of Natural science in elementary school based multimedia android using Augmented Reality. The development that conducted is using procedural model that adapting Borg and Gall model development.

The development consists of ten steps: (1) research and information collecting (2) Planning (3) Develop preliminary form of product(4) Preliminary field testing (5) main product revision (6) main field testing to validate development product in large scale and compared with control product (7) operational product revision (8) operational field testing. It is validation test towards operational product that produced (9) Final product revision (10) dissemination and implementation product (Puslitjaknov, 2008; Setyosari, 2010).

Respondent in this research is class elementary school students in Surakarta. In the trial of small scale, the product is tested to10 students and1teacher. In the trial of middle scale, the product is tested to 25 students and 2 teachers. Then, in the trial of large scale, it is tested to six classes (control class and experiment class). Instruments that used in this development research are questionnaire, questions, validation sheet, assessment sheet between students and observation sheet. Data processing in this research is conducted using descriptive analysis, including: expediency analysis and analysis of learning test result data.

The method of collecting data in this research is questionnaire technique to know the expediency product (assignment work sheet based android multimedia) from topic experts, language experts, learning experts, media experts, and also the teacher and students' respond, learning result assessment, psychomotor, and behavior. Test technique to assess cognitive learning result, and assessment technique inter students to psychomotor and behavior. Before tested, product is validated by experts using Aiken formula. 


\section{RESULT AND DISCUSSION}

\section{Research and Information Collection}

Activities conducted on the needs analysis in the form of field studies by giving questionnaires to students and teachers to the needs of learning media, learning condition in the classroom, the availability of learning materials, interviews with students and teachers, and analysis of national examination results in the last three years and daily test results.

In this preliminary research, it is found that the learning result of natural science is not yet optimal, there are some topics that are difficult to be understood by the students, especially the topic that need analysis process to an image and cycle. Thus, teachers need natural science learning media that appeals to learners and facilitates the students' understanding in learning natural science.

\section{Planning}

In this stage, the researcher design learning media based android multimedia by utilizing augmented reality based on KTSP curriculum.

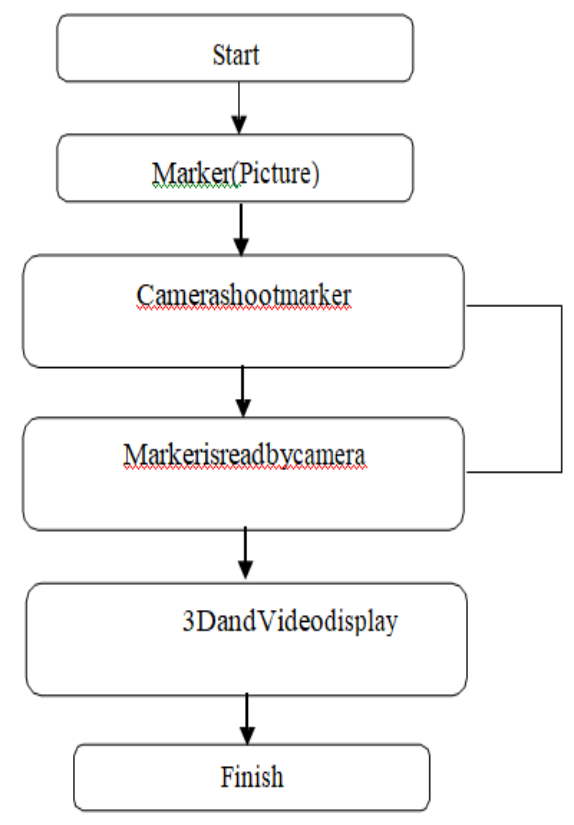

Picture 1. Augmented Reality Mechanism

\section{Develop Preliminary form of Product}

Researchers make learning media based on augmented reality technology based on the grade of elementary school. The resulting product has been validated by experts covering material experts, media experts, learning experts, linguists, and education practitioners. The results obtained that the media developed is valid with the acquisition of validation value Aiken 0.9528 .

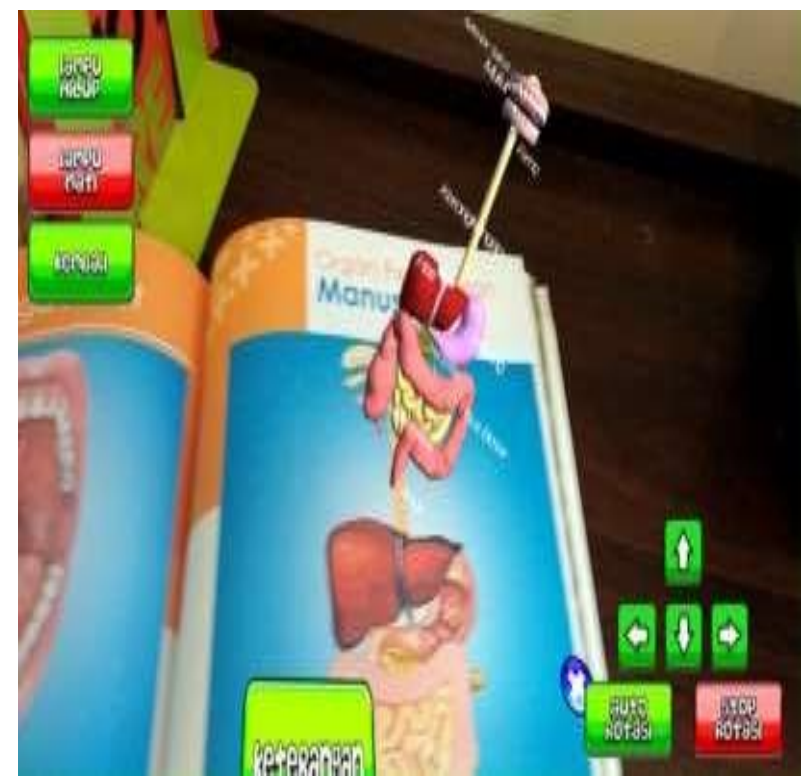

Picture 2. Display of Augmented Reality

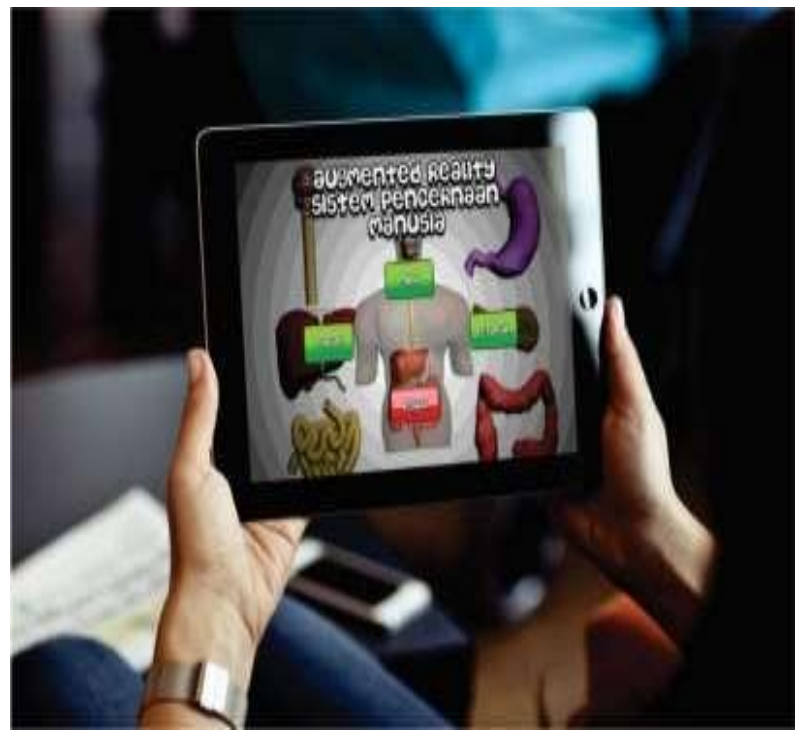

Picture 3. Display of Application in android

\section{Preliminary Field Testing}

In preliminary field testing stage, product was tested to 10 students and 
2teachers. The aim of preliminary fieldtesting was to measure read ability of product that was media. Furthermore, this test was conducted by distributing questioner to the students and teachers after they used the product. The result shows that the quality of developed media was average. The data analysis shows that students mean score in evaluating product is 83.96 , and evaluation product from teacher is 81.25 .

\section{Main Product Revision}

Main product revision was do net revise the product by considering on the result of preliminary field-testing. Revision was conducted from students' evaluation and teachers' evaluation toward the product. The revision includes improving the quality of sensitivity marker in augmented reality and others inappropriate terms.

\section{Main Field Testing}

In this stage, product was tested in to larger scale. Developed media was tested in to one class with the total number of students was 25 students and 2 teachers. The result shows that the quality of media is good. Students' evaluation score was 88.07 and teachers' evaluation score was 92.71

Table 1. The Result of Main Field Testing

\begin{tabular}{llllll}
\hline No & $\begin{array}{l}\text { Evaluation } \\
\text { Aspect of Quality }\end{array}$ & \multicolumn{2}{c}{ Students } & \multicolumn{2}{c}{ Teacher } \\
& & $\begin{array}{l}\text { Persentage } \\
(\%)\end{array}$ & Category & $\begin{array}{l}\text { Persentage } \\
(\%)\end{array}$ & Category \\
\hline 1. & Content & 86,74 & Good & 91,67 & Good \\
2. & Language & 89,77 & Good & 91,67 & Good \\
3. & Display & 88,26 & Good & 91.67 & Good \\
4. & Abandonment & 87,5 & Good & 95,83 & Good \\
& Mean & 88,07 & Good & 92,71 & Good \\
\hline
\end{tabular}

\section{Operational Product Revision}

The quality revision and improvement of the product was done based on the result of main field-testing. In this stage, the quality revision and improvement was conducted by adding the explanation voice on augmented reality display.

\section{Operational Field Testing}

Operational field test in go developed media was conducted in 3 sample schools. The result of implementing the developed media in learning process shows the optimal result. It can be showed from the improvement of students learning outcome in some aspects such as cognitive, affective, and psychomotor. The following tables show the improvement score of students' learning outcome on.

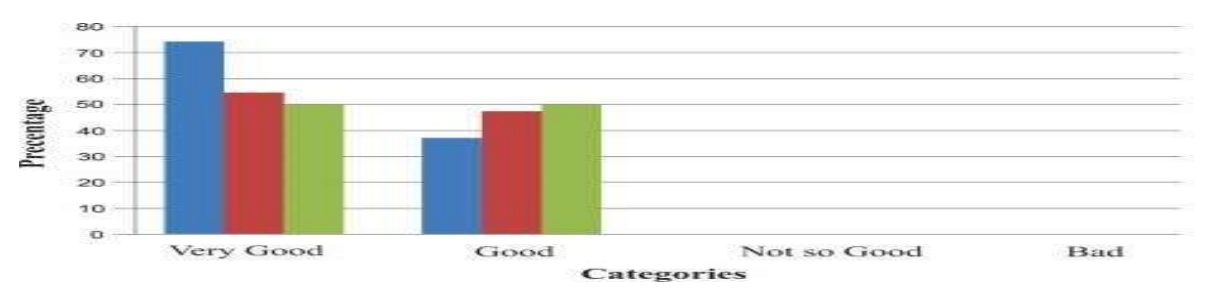

Experiment school 1
Experiment school 2 Experiment school 3

Graphic 1. Mean Score of students' Cognitive Score 


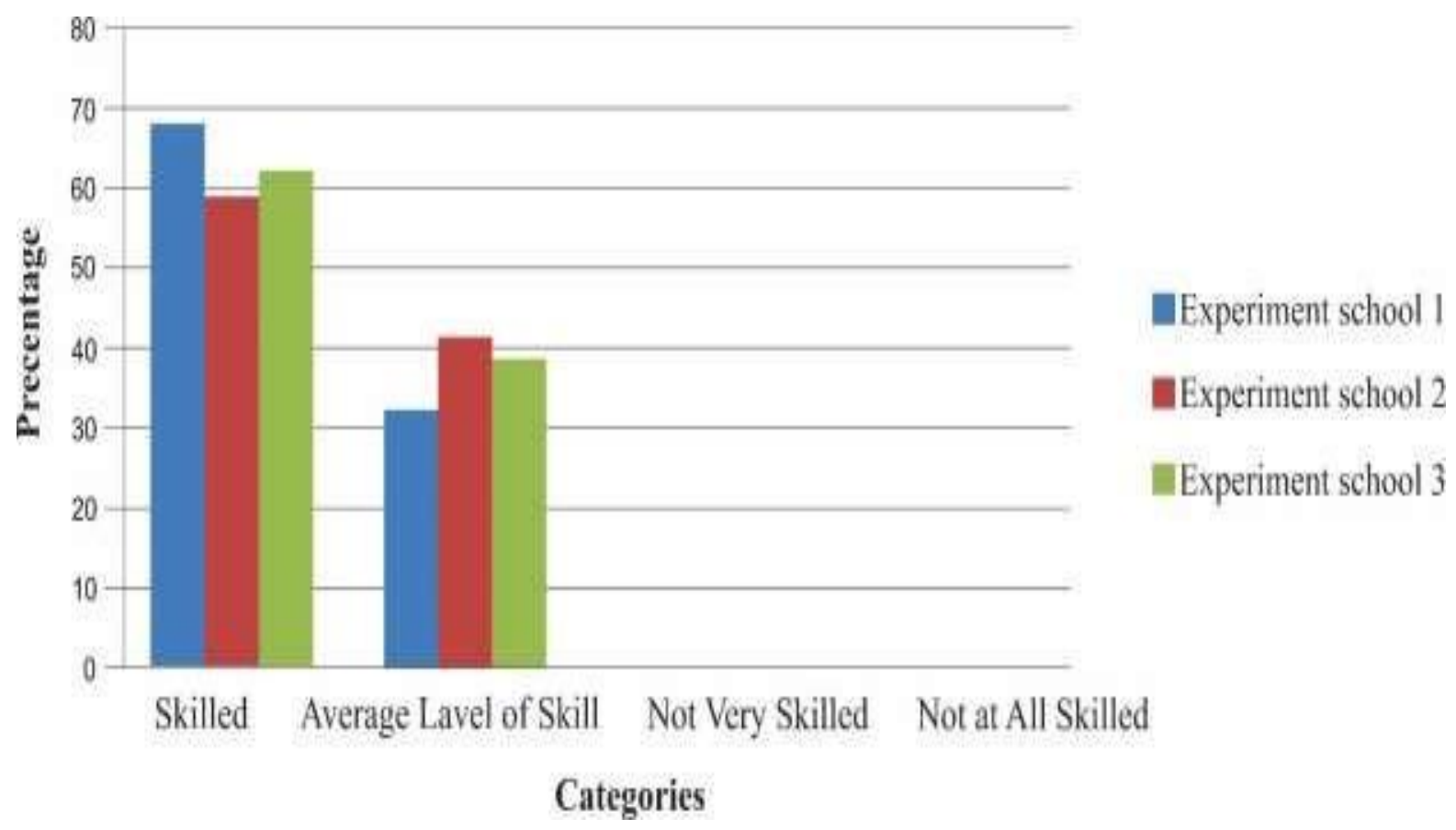

Graphic 2. Students' Learning outcome in Affective Aspect

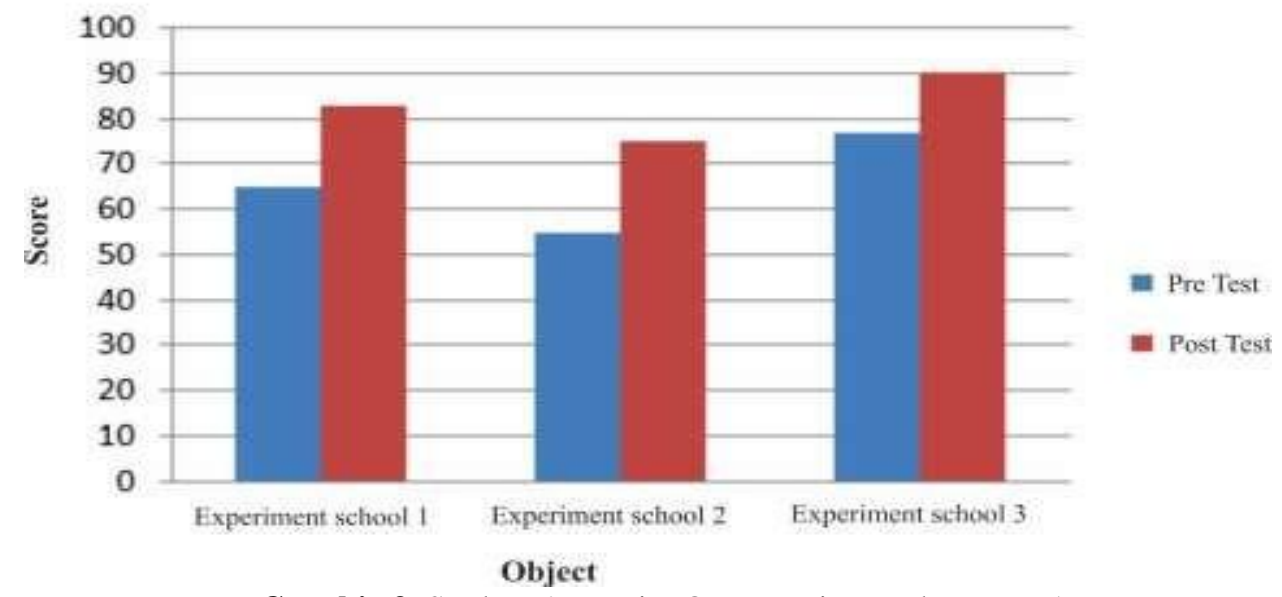

Graphic 3. Students'LearningOutcome in Psychomotor Aspect

\section{Final Product Revision}

Final product revision was conducted based on the result of operational field testing that shows that the quality of product is appropriate and relevant to be implemented and disseminated.

\section{Dissemination and Implementation}

After validation, testing and revision leaning media of science using augmented reality is appropriate and relevant to be implemented in learning process. The next stage is disseminating and implementing product. Furthermore, the developed product is presented in learning innovation for amend distributed to schools in Surakarta. Later on, play store is used to enlarge the distribution of produce and easy teachers and students to access and download the product.

\section{CONCLUSION AND RECOMMENDATION}

In this research, researcher developed learning science media by using augmented 
reality technology. The product was validated by experts including media expert, learning expert, language expert and education practitioners. The result of validation shows that the developed media score was 0.9528 . The result of students' evaluation and teachers' evaluation toward the product was $88.07 \%$ and $92.71 \%$.It means that the developed product is good and relevant to be implemented in learning process. Moreover, the result of field testing also shows significant result.

The result of field-testing shows that the developed media can improve students' learning outcome on science viewed from cognitive aspect, affective aspect and psychomotor aspect. In the last stage of this development research, researcher disseminates the product to the elementary school teachers in Surakarta, distributes and provides download facility of product in play store.

\section{REFERENCES}

Banks, J., Cochran-Smith, M., Moll, L., Richert, A., Zeichner, K., Le Page, P. McDonald, M. (2005). Teaching diverse learners. Preparing Teachers for a Changing World: What Teachers Should Learn and Be Able to Do, 2005, 232-274.

Baumert, J., Klieme, E., Neubrand, M., Prenzel, M., Schiefele, U., Schneider, W., WEI, M. (2001). Program for international student assessment. Schülerleistungen Im Internationalen Vergleich. Berlin: Max-Planck-Institut Für Bildungsforschung.

Biggs, J. B. (2011). Teaching for quality learning at university: What the student does. McGraw-Hill Education (UK).

Bujak, K. R., Radu, I., Catrambone, R., Macintyre, B., Zheng, R., \& Golubski, G. (2013). A psychological perspective on augmented reality in the mathematics classroom. Computers \& Education, 68, 536-544.

Bybee, R. W. (2009). Program for international student assessment (PISA) 2006 and scientific literacy: a perspective for science education leaders. Science Educator, 18(2), 113.

Chiang, T. H., Yang, S. J., \& Hwang, G.-J. (2014). Students' online interactive patterns in augmented reality-based inquiry activities. Computers \& Education, 78, 97-108.

Chittaro, L., \& Ranon, R. (2007). Web3D technologies in learning, education and training: Motivations, issues, opportunities. Computers \& Education, 49(1), 3-18.

Council, N. R. (2000). Inquiry and the national science education standards: A guide for teaching and learning. National Academies Press.

Dick, W., Carey, L., Carey, J. O., \& others. (2001). The systematic design of instruction (Vol. 5). Longman New York.

Dunleavy, M., Dede, C., \& Mitchell, R. (2009). Affordances and limitations of immersive participatory augmented reality simulations for teaching and learning. Journal of Science Education and Technology, 18(1), 7-22.

Duschl, R. (2008). Science education in threepart harmony: Balancing conceptual, epistemic, and social learning goals. Review of Research in Education, 32(1), 268-291.

Elango, P. (2013). Sistem pemulihan lembaran kerja bagi nombor negatif berasaskan realiti luasan (AR2WN2). Universiti Kebangsaan Malaysia, Bangi.

Feiner, S., Macintyre, B., \& Seligmann, D. (1993). Knowledge-based augmented 
reality. Communications of the ACM, 36(7), 53-62.

Hill, J. R., \& Hannafin, M. J. (2001). Teaching and learning in digital environments: The resurgence of resource-based learning. Educational Technology Research and Development, 49(3), 37-52.

Höllerer, T., \& Feiner, S. (2004). Mobile augmented reality. Telegeoinformatics: Location-Based Computing and Services. Taylor and Francis Books Ltd., London, UK, 21.

Hurd, P. D. (1998). Scientific literacy: New minds for a changing world. Science Education, 82(3), 407-416.

Jimoyiannis, A. (2010). Designing and implementing an integrated technological pedagogical science knowledge framework for science teachers professional development. Computers \& Education, 55(3), 12591269.

Karampiperis, P., \& Sampson, D. (2005). Adaptive learning resources sequencing in educational hypermedia systems. Journal of Educational Technology \& Society, 8(4).

Kaufmann, H. (2003). Collaborative augmented reality in education. Institute of Software Technology and Interactive Systems, Vienna University of Technology.

Kaufmann, H., \& Schmalstieg, D. (2003). Mathematics and geometry education with collaborative augmented reality. Computers \& Graphics, 27(3), 339345.

Kaufmann, H., Schmalstieg, D., \& Wagner, M. (2000). Construct3D: a virtual reality application for mathematics and geometry education. Education and Information Technologies, 5(4), 263-276.
Kirner, T. G., Reis, F. M. V., \& Kirner, C. (2012). Development of an interactive book with augmented reality for teaching and learning geometric shapes. In Information Systems and Technologies (CISTI), 2012 7th Iberian Conference on (pp. 1-6). IEEE.

Koper, R. (2003). Combining re-usable learning resources and services to pedagogical purposeful units of learning. Reusing Online Resources: A Sustainable Approach to ELearning, 46-59.

Küçük, S., Yilmaz, R., \& Göktas, Y. (2014). Augmented reality for learning English: achievement, attitude and cognitive load levels of students. Egitim ve Bilim, 39(176).

Lee, K. (2012). Augmented reality in education and training. TechTrends, 56(2), 13-21.

Liu, Y. (2010). Social media tools as a learning resource. Journal of Educational Technology Development and Exchange (JETDE), 3(1), 8.

Neo, M., \& Neo, K. T. (2001). Innovative teaching: Using multimedia in a problem-based learning environment. Educational Technology \& Society, 4(4), 19-31.

Puslitjaknov, T. (2008). Metode penelitian pengembangan. Jakarta: Departemen Pendidikan Nasional.

Sanjaya, W. (2008). Kurikulum Dan Pembelajaran (Teori \& Praktek KTSP). Kencana.

Setyosari, P. (2010). Metode penelitian pendidikan dan pengembangan. Jakarta: Kencana.

So, H.-J., \& Kim, B. (2009). Learning about problem based learning: Student teachers integrating technology, pedagogy and content knowledge. 
Australasian Journal of Educational Technology, 25(1), 101-116.

Sommerauer, P., \& Müller, O. (2014). Augmented reality in informal learning environments: A field experiment in a mathematics exhibition. Computers \& Education, 79, 59-68.

Trinova, Z. (2012). Hakikat Belajar dan Bermain Menyenangkan bagi Peserta Didik. Al-Ta Lim Journal, 19(3), 209215.

Van Krevelen, D. W. F., \& Poelman, R. (2010). A survey of augmented reality technologies, applications and limitations. International Journal of Virtual Reality, 9(2), 1.

Wojciechowski, R., \& Cellary, W. (2013). Evaluation of learners' attitude toward learning in ARIES augmented reality environments. Computers \& Education, 68, 570-585.

Zhou, F., Duh, H. B.-L., \& Billinghurst, M. (2008). Trends in augmented reality tracking, interaction and display: A review of ten years of ISMAR. In Proceedings of the 7th IEEE/ACM International Symposium on Mixed and Augmented Reality (pp. 193-202). IEEE Computer Society. 